\title{
Beberapa Parameter Biokimia Darah Ayam Ras Petelur Fase Grower dan Layer dalam Lingkungan "Upper Zonathermoneutral"
}

\section{Some Biochemistry Parameters of Grower and Laying Hens in Upper Zonathermoneutral}

\author{
A. Mushawwir dan D. Latipudin \\ Laboratorium Fisiologi Ternak dan Biokimia, Fakultas Peternakan \\ Universitas Padjadjaran, Kampus Jatinangor, Bandung 45363 \\ e-mail: andimushawwir1975@gmail.com \\ (Diterima: 1 Juli 2011; Disetujui: 29 September 2011)
}

\begin{abstract}
Twenty grower and laying hens housed indoors in individual cages were used to explore the profile to some biochemistry parameters on grower and laying hens in upper zonathermoneutral (average: $31.5^{\circ} \mathrm{C}$ ). This study was conducted in poultry housing at CV. Pamulihan Farm Kuningan, Jawa Barat, for two months. Blood samples free protein were used to determined glucose, blood plasma for cholesterol, and blood serum were used to determined albumin, globulin and protein total. Biochemistry Parameters in this study were analyzed by spectrophotometer technique. Results of this study indicated that there were significantly effect of temperature on the albumin, globulin, total protein, and glucose. This results has been proved to be a good indicator for predicting heat stressed in laying hens. Based on this results of study, it may be a consideration for a good feed strategy to laying hens in upper zonathermoneutral.
\end{abstract}

Keywords: blood biochemistry, hen, temperature

\section{PENDAHULUAN}

Produktifitas ayam petelur yang tinggi menjadi isu penting dalam rangka pemenuhan konsumsi protein hewani. Faktor lingkungan terutama temperatur merupakan salah satu faktor penting yang sangat mempengaruhi produktifitas ternak tersebut. Temperatur yang tinggi secara langsung memacu pengeluaran panas yang tinggi (Yahav et al., 2004).

Pengeluaran panas merupakan mekanisme fisiologik yang kompleks bagi ternak sebagai kelompok hewan hemotermik guna mempertahankan temperatur tubuh untuk mempertahankan kelangsungan metabolisme normal. Namun, mekanisme ini melibatkan sistem yang kompleks terhadap organ kardiovaskuler, sistem immun, respirasi, dan sebagainya (Yahav, 2000).

Untuk mendukung mekanisme ini, maka metabolisme biomolekul dan sistem immun akan menjadi sangat dinamis guna mempertahankan metabolisme yang normal untuk tujuan hidup pokok lebih dahulu. Oleh karena itu status biologis ternak baik jenis kelamin maupun fase pertumbuhannya, memberikan kontribusi langsung dalam merespon cekaman panas. Puvadolpirod dan Thaxton (2000) dan Mumma et al. (2006) menunjukkan bahwa albumin, globulin dan total protein serum/plasma darah serta glukosa dan koleseterol merupakan biomolekul yang penting sebagai penanda ternak stress panas.

Penelitian ini bertujuan untuk mengetahui perbandingan respon ternak ayam petelur fase grower dengan layer dalam merespon cekaman panas lingkungan.

\section{METODE}

\section{Ayam Percobaan, Kandang dan eralatan}

Empat puluh ekor ayam ras petelur strain ISA petelur, masing-masing 20 ekor fase grower dan layer, masing-masing 
berumur 12 minggu dan 40 minggu pada awal pemeliharaan. Rataan berat badan masing - masing fase $505 \pm 8,4 \mathrm{~g}$ dan $1105 \pm 17$ g. Penelitian ini dilakukan selama 2 bulan pada musim kemarau (Juni-Agustus 2011), dengan rata-rata temperatur lingkungan selama masa penelitian adalah $31,5^{\circ} \mathrm{C}$. Ayam percobaan ditempatkan dalam kandang battery individual cage. Tiap petak kandang dilengkapi dengan tempat pakan dan minum.

\section{Teknik Pengukuran Sampel}

Pengambilan sampel darah ternak sampel, masing-masing dilakukan dua kali yaitu pada akhir bulan pertama dan kedua. Preparasi sampel darah telah dilakukan agar diperoleh filtrat darah bebas protein berdasarkan metode Folin-Wu dan Somogyi untuk penetapan kadar glukosanya, dan serum digunakan untuk penetapan kadar albumin, globulin, total protein darah, sedangkan penetapan kadar kolesterol digunakan plasma darah.

Preparasi serum dilakukan dengan menggunakan tabung penampung darah tanpa EDTA/heparin sebagai anti koagulan 9 $\mathrm{mL}$. Darah diambil melalui vena jugularis dan ditampung dalam tabung kurang lebih 6 $\mathrm{mL}$. Agar diperoleh serum darah yang banyak, maka tabung ditempatkan dalam keadaan miring kurang lebih $45^{\circ}$ guna memperluas permukaan darah. Cairan bening kekuningan akan berada disebelah atas darah, cairan ditampung ke dalam kuvet berukuran $4 \mathrm{~mL}$.

Analisis atau pembacaan kadar kolesterol dan glukosa dilakukan dengan teknik spektrofotometrik. Serapan kadar glukosa dibaca dengan panjang gelombang $420 \mathrm{~nm}$. Penetapan kadar glukosa dilakukan dengan metode Folin-Wu. Prinsip kerja metode ini adalah memanfaatkan sifat glukosa sebagai sebuah aldosa (bergugus aldehid atau rantai rangkap karbon yang berikatan dengan oksigen berada di ujung rantai karbon). Aldehid mampu mereduksi senyawa kupro pada pewarna phosphomolibdat yang berwarna biru. Intensitas warna biru menyatakan konsentrasi tembaga yang direduksi dan dengan demikian menyatakan konsentrasi glukosa. Larutan dan bahan yang digunakan terdiri dari filtrat darah bebas protein, standar glukosa, pereaksi tembaga alkalis, dan asam fosfomolidbat. Nilai serapan yang telah dicatat pada kuvet blanko, standar dan kuvet plasma darah yang diuji, dianalisis dengan rumus berikut :

Kadar Glukosa $=\frac{A u-A b}{A s-A b} \times 0,2 \times \frac{100}{0,2} \mathrm{mg}$. dL10 ${ }^{-1}$

Keterangan : $\mathrm{Au}=$ Serapan sampel yang diuji $\mathrm{Ab}=$ Serapan blanko As $=$ Serapan standar

Analisis kadar protein serum total, dilakukan dengan menggunakan prinsip uji biuret. Ion $\mathrm{Cu}^{2+}$ bereaksi dengan ikatan peptida dalam larutan alkalis menghasilkan kompleks senyawa berwarna lembayung. Intensitas warna yang terbentuk berbanding lurus dengan konsentrasi proteinnya. Larutan sampel uji, standar, dan blanko dibaca serapannya pada panjang gelombang $540 \mathrm{~nm}$. Nilai baca serapan dianalisis dengan rumus berikut :

Kadar protein $=\frac{A u-A b}{A s-A b} \times 6$ g.dL10 1

Analisis kadar albumin telah dilakukan dengan menggunakan teknik pewarnaan bromkesol hijau. Bromkesol hijau merupakan pewarna anionik yang dapat berikatan erat dengan protein albumin, kompleks senyawa yang terbentuk dapat menyerap cahaya dengan panjang gelombang $628 \mathrm{~nm}$. Hasil baca serapan dianalisis dengan rumus berikut :

$$
\begin{aligned}
& \text { Kadar Albumin }=\frac{A u-A b}{A s-A b} \times 6 \text { g.dL10 } \\
& \text { Kadar globulin serum diperoleh } \\
& \text { dengan mengurangi kadar protein total } \\
& \text { dengan kadar albumin. } \\
& \text { Analisis Statistika } \\
& \text { Data yang telah dikumpulkan } \\
& \text { dianalisis dengan menggunakan uji T- }
\end{aligned}
$$

\section{Analisis Statistika}


student dengan populasi tidak berpasangan (Steel dan Torrie, 1993), pengujian telah dilakukan dengan varians yang sama, dengan langkah sebagai berikut :

- Populasi $\mathrm{x}=$ ayam petelur fase grower.

- Populasi y = ayam petelur fase layer.

1. Rata-rata hitung

$$
\bar{X}=\frac{\sum(x)_{1}}{N}
$$

2. Simpangan Baku

$$
\mathrm{S}=\frac{\sqrt{\sum \mathrm{x}^{2}-\frac{1}{n}(\Sigma \mathrm{x})^{2}}}{\mathrm{n}-1}
$$

3. Koefisien Variasi (KV)

$$
\begin{aligned}
& \mathrm{Kv}=\frac{S}{X} \times 100 \% \\
& \mathrm{KV}=\frac{\text { simpanganvakr }}{\text { rata-rata }} \times 100 \%
\end{aligned}
$$

4. Menghitung varians dari masing-masing variabel

$$
S x^{2}=\frac{\sum \mathrm{xi}^{2}-\frac{\left(\sum \mathrm{x}\right)^{2}}{\mathrm{n}}}{\mathrm{n}-1} \quad S y^{2}=\frac{\sum \mathrm{yi}^{2}-\frac{\left(\sum \mathrm{y}\right)^{2}}{\mathrm{n}}}{\mathrm{n}-1}
$$

Keterangan :

$\mathrm{Sx}^{2}=$ Varians sampel ayam petelur fase grower $\mathrm{Sy}^{2}=$ Varians sampel ayam petelur fase layer

5. Menguji keseragaman

$$
F=\frac{\text { Varians yang besar }}{\text { Varians yang kecil }}, \alpha\left(\mathrm{n}_{1}-1 ; \mathrm{n}_{2}-1\right)
$$

Jika : $\mathrm{F}$ hitung $>\mathrm{F}$ table $=$ Varians sama $\mathrm{F}$ hitung $<\mathrm{F}$ table $=$ Varians tidak sama

Keterangan :

$\mathrm{F}=$ Keseragaman populasi $\mathrm{n}_{1}$

$\mathrm{n}_{1}=$ Jumlah sampel ayam petelur fase grower

$\mathrm{n}_{2}=$ Jumlah sampel ayam petelur fase layer

6. Untuk varians yang sama

$$
\mathrm{S} \bar{d}=\sqrt{\mathrm{S}_{\mathrm{p}^{x}}\left(\frac{1}{\mathrm{n}_{1}}+\frac{1}{\mathrm{n}_{\mathrm{n}}}\right)}
$$

Dimana :

$$
\begin{aligned}
& S_{p}{ }^{2}=\frac{\left(\mathrm{n}_{1}-1\right) \mathrm{Sx}^{2}+\left(\mathrm{n}_{2}-1\right) \mathrm{Sy}^{2}}{\mathrm{n}_{1}+\mathrm{n}_{2}-2} \\
& \text { Statistik Uji: } \quad t=\frac{\overline{\mathrm{x}}-\overline{\mathrm{y}}}{\mathrm{S} \bar{d}}
\end{aligned}
$$

Keterangan :

$\mathrm{S} \bar{d}=$ Varians.

$$
\begin{aligned}
& S p^{2}=\text { Varians gabungan ayam petelur fase } \\
& \quad \text { grower dan ayam petelur fase layer. } \\
& S x^{2}=\text { Varians sampel ayam petelur fase grower. } \\
& S y^{2}=\text { Varians sampel ayam petelur fase layer. } \\
& \bar{x} \quad \text { Rata-rata parameter sampel ayam petelur } \\
& \quad \begin{array}{c}
\text { fase grower. } \\
=
\end{array} \\
& \quad \text { Rase layer }
\end{aligned}
$$

\section{HASIL DAN PEMBAHASAN}

Rata-rata konsentrasi parameter biokimia darah sebagai indikator respon cekaman temperatur lingkungan pada kelompok fase biologis ayam petelur yang berbeda, ditampilkan pada Tabel 1 dan profil perbedaannya ditampilkan pada Gambar 1 .

\section{Dinamika Protein Darah}

Albumin, globulin merupakan komponen protein darah yang penting. Albumin, selain berfungsi sebagai zat pengangkut bermacam-macam molekul yang lebih kecil di dalam darah, misalnya asam-asam lemak, pigmen-pigmen empedu. Selain sebagai zat pengangkut juga berperan sebagai prekursor sel-sel darah putih sebagai zat immun. Globulin komponen darah sangat penting karena anti bodi merupakan globulin gamma (Hicks et al., 1998).

Hasil penelitian (Tabel 1 dan Gambar 1) menunjukkan bahwa konsentrasi albumin dan globulin lebih tinggi pada ayam fase grower dibandingkan layer, sedangkan total protein lebih tinggi pada fase layer (Tabel 1). Hasil penelitian ini menunjukkan perbedaan respon ayam tersebut terhadap cekaman panas hingga timbulnya stress. Status biologis ternak yang berbeda (grower dan layer) akan memberikan respon stress yang berbeda, hal ini terkait dengan aktifitas biologisnya dalam memacu metabolisme untuk kepentingan sintesis telur.

Mekanisme munculnya stres pada hakikatnya merupakan mekanisme yang melibatkan neuroendokrin (Dawson et al., 2000; Shinder et al., 2007). Respon neuroendokrin sebagai dampak stress antara lain dilaporkan oleh Von Borell (2001), yang ditunjukkan melalui peran sistem 
syaraf pusat $(\mathrm{CNS}=$ Centre Nervous System) dalam menerima rangsangan stress serta hubungannya dengan Corticotrpic Relasing Hormon (CRH), kelenjar endokrin dan sistem immune. Stressor stress antara lain cekaman panas yang dapat timbul bagi ternak ayam yang dipelihara dalam kondisi diatas zona nyamannya (upper zonathermoneutral).

Tabel 1. Rata-rata Konsentrasi Parameter Biokimia Darah Ayam Ras Petelur Fase Grower dan Layer sebagai Indikator Respon Cekaman Temperatur Lingkungan.

\begin{tabular}{|c|c|c|}
\hline \multirow{2}{*}{$\begin{array}{c}\text { Parameter Biokimia Respon } \\
\text { Stress }\end{array}$} & \multicolumn{2}{|c|}{ Fase Biologis } \\
\hline & Grower & Layer \\
\hline Albumin Serum (g.dL10 $\left.{ }^{-1}\right)$ & $0,12^{\mathrm{a}}$ & $0,07^{\mathrm{b}}$ \\
\hline Globulin Serum (g.dL10 ${ }^{-1}$ ) & $0,06^{\mathrm{a}}$ & $0,03^{\mathbf{b}}$ \\
\hline Total Protein Darah (g.dL10 $0^{-1}$ ) & $2,93^{\mathrm{a}}$ & $3,42^{\mathrm{b}}$ \\
\hline $\begin{array}{l}\left.\text { Glukosa plasma (mg. dL } 10^{-1}\right) \\
\left.\text { Kolesterol Plasma (mg. dL10 } 10^{-1}\right)\end{array}$ & $\begin{array}{l}255^{\mathrm{a}} \\
114^{\mathrm{a}}\end{array}$ & $\begin{array}{l}267^{\mathrm{b}} \\
118^{\mathrm{a}}\end{array}$ \\
\hline
\end{tabular}

Keterangan : Superskrip yang berbeda pada baris yang sama menunjukkan perbedaan rata-rata parameter pada $\alpha 0,01$
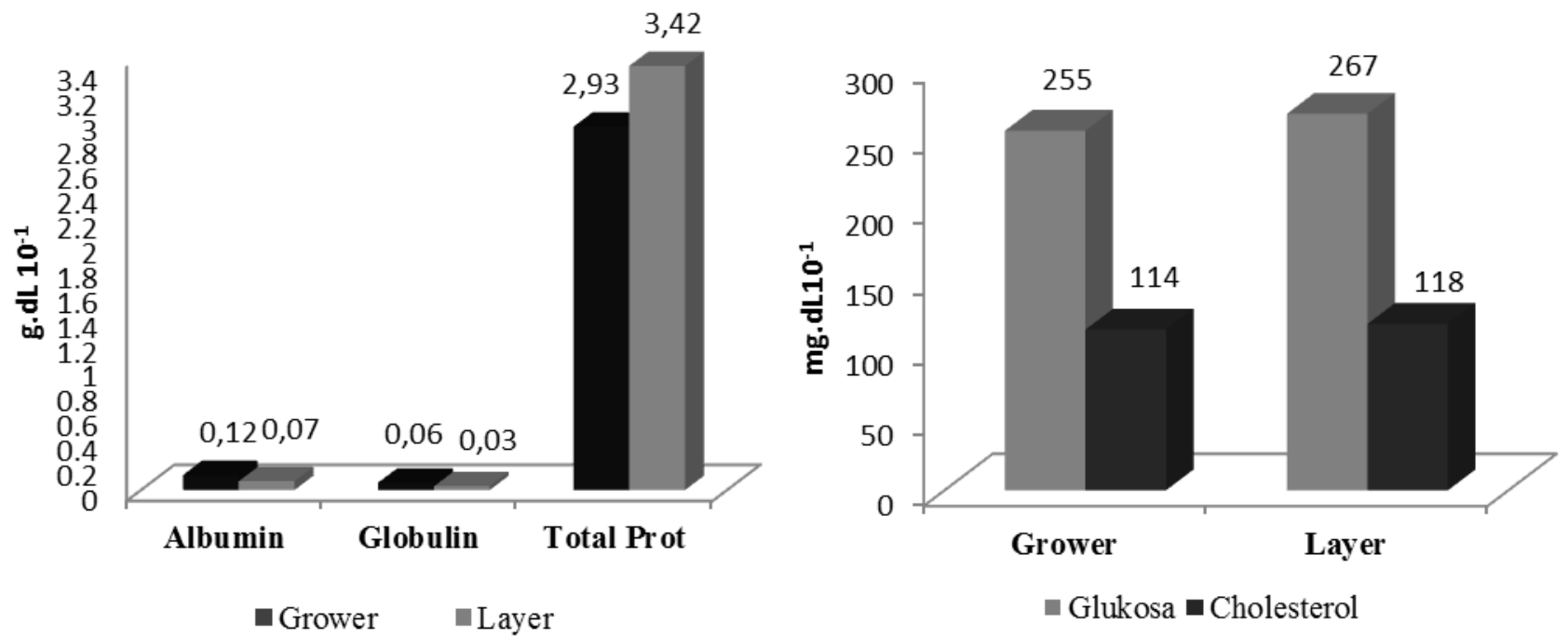

Gambar 1. Profil Rata-rata Konsentrasi Parameter Biokimia Darah Ayam Ras Petelur Fase Grower Dan Layer sebagai Indikator Respon Cekaman Temperatur Lingkungan. 


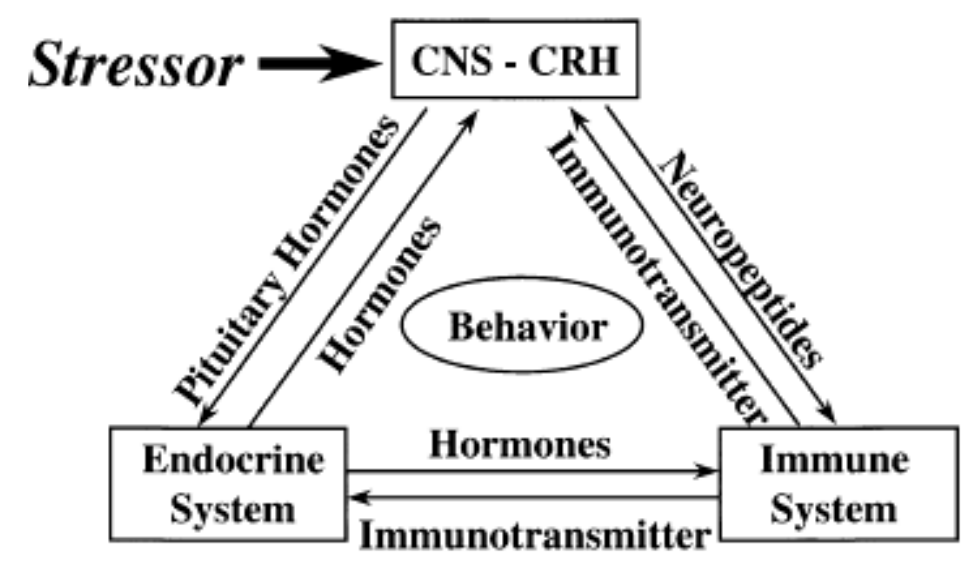

Gambar 2. Interrelasi sistem syaraf pusat $(\mathrm{CNS}=$ Centre Nervous System) dalam menerima rangsangan stress serta hubungannya dengan Corticotrpic Relasing Hormon (CRH), Kelenjar Endokrin, dan Sistem Immun.

Terkait hubungannya dengan protein darah (total, albumin dan globulin) dapat dijelaskan bahwa stress yang diterima dari stressor berupa cekaman panas merupakan hasil dari interrelasi mekanisme kerja organ (Aengwanich, 2007), sebagaimana ditunjukkan pada Gambar 2.

Pada Gambar 2 tampak bahwa stressor berupa cekaman panas yang diterima oleh syaraf efferent, yang berada pada seluruh permukaan tubuh ke sistem syaraf pusat (CNS). Ransangan tersebut diteruskan ke sistem kelenjar endokrin dan organ-organ yang terkait. Organ inilah yang memberikan respon terhadap cekaman yang dihadapai oleh ternak.

Rendahnya kadar albumin dan globulin (Gambar 1) pada fase layer disebabkan oleh aktifitas metabolisme nutrien sebagian besar ditujukan untuk pembentukan telur, oleh karena itu terdapat penurunan aktifitas sistem immun pada fase layer dibandingkan fase grower. Protein-protein darah termasuk albumin dan globulin, disintesis di dalam sel sebagai respon sinyal transduksi atas terbentuknya kompleks estrogen dengan reseptornya (Gomperts et al., 2009). Aktifitas ini lebih tinggi pada fase layer karena ditujukan untuk memenuhi komposisi protein putih telur, seperti albumin, globulin, avomucoid, ovomucin, ovotransferrin, flavoprotein, avidin, ovoinhibitor (Bell and
Freeman, 1971; Mahmoud et al., 2010; Tan et al., 2010). Peningkatan sintesis protein pada fase layer inilah yang menjadi penyebab kadar protein total pada fase layer lebih tinggi dibandingkan grower. Berdasarkan hasil penelitian ini menunjukkan bahwa fase grower memiliki respon immunitas lebih baik dibandingkan dengan fase layer.

\section{Fenomena Metabolisme Terkait Energi}

Glukosa dan kolesterol merupakan molekul penting dalam sistem metabolisme, karena peranannya sebagai sumber energi maka keduanya memiliki profil yang cenderung statis pada ternak, berbeda dangan manusia yang sangat dinamis kadarnya dalam darah.

Pada Tabel 1 dan dan Gambar 1 menunjukkan bahwa kadar glukosa darah lebih tinggi pada fase layer dibanding grower, sedangkan kolesterol tidak berbeda. Tingginya kadar glukosa pada fase layer merupakan mekanisme penyediaan energi dalam keadaan ayam fase layer terpapar cekaman panas, sehingga produksi glukosa lebih tinggi untuk memenuhi dua kepentingan yaitu hidup pokok dan produksi telur. Sedangkan kolesterol tampak tidak berbeda karena stress meningkatkan glikoneogenesis sehingga asam lemak maupun kolesterol sebagian 
dikonversi menjadi glukosa. Sebagai kompensasi sintesis kolesterol yang rendah pada ayam dalam lingkungan terpapar cekaman panas menyebabkan produksi telur menurun, karena salah satu komponen penting telur adalah kolesterol.

Peningkatan kadar kolesterol ini dapat dijelaskan juga bahwa peranan Corticotropin-releasing hormone (CRH) yang disekresikan oleh hypotalamus sebagai respon cekaman panas, menginduksi pituitary anterior untuk mensekresikan Adrenocorticoid Tirotropin Hormon (ACTH), selanjutnya ACTH merangsang adrenal cortex untuk menghasilkan hormon-hormon glucocorticoid dan epinephrin oleh adrenal medulla (von Borell, 2001; Hardy et al., 2005; Garriga et al., 2006)
Glucocorticoid terutama berpengaruh terhadap metabolisme karbohidrat, lemak dan protein. Cortisol menyebabkan level asam amino dalam darah meningkat akibat efek katabolik cortisol terhadap otot, dan selanjutnya berakibat sangat melemahkan perototan. Transport asam-asam amino menyeberangi dinding sel-sel ekstrahepatik menurun, akan tetapi dibawah pengaruh cortisol terjadi peningkatan transportnya ke dalam sel-sel hati. Mobilisasi ini berlangsung bersamaan dengan : (1) konversi asam amino menjadi glukosa (glukoneogenesis); (2) meningkatnya pembentukan plasma dan protein hati oleh hati, dan (3) proses deaminasi dalam hati meningkat (Hardy et al., 2005).

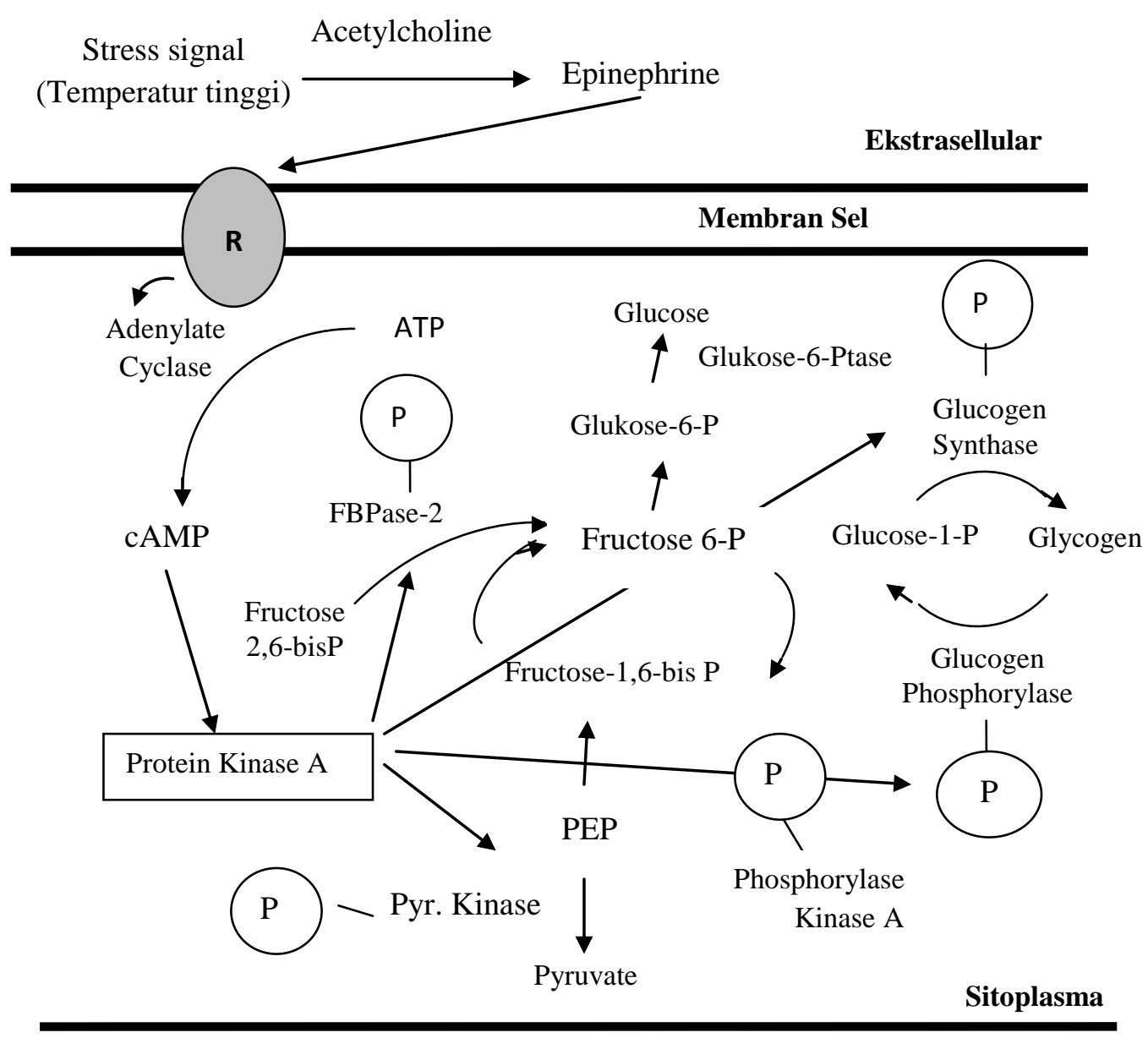

Gambar 3. Peranan Epinephrin dalam Menginduksi Reseptor Adenylate Cyclase untuk Mengaktifkan cAMP untuk Memproduksi Glukosa dalam Rangka Pemenuhan Energi sebagai Dampak Tekanan Stres 
Rahardja (2010) mengemukakan peranan cortical dalam metabolisme lemak. Pengaruh cortisol terhadap metabolisme lemak masih banyak mengundang perdebatan. Glukoneogenesis yang diinduksi oleh cortisol cenderung mengkatabolis depot-depot lemak, dan pada sekresi cortisol yang berlebihan (hypersecretion) sering kali menyebabkan "pendulous abdomen" atau kulit perut menggelambir pada mamalia. Mobilisasi depot-depot lemak menyebabkan peningkatan level asam lemak dalam sirkulasi, sehingga memungkinkan penggunaannya untuk energi atau konversinya menjadi glikogen hati.

Hormon-hormon corticoid adrenal (glucocorticoid dan mineralocorticoid) kemungkinan bekerja meningkatkan respons jaringan target terhadap glucagon, epinephrine dan mungkin hormon-hormon lain yang menstimulasi proses metabolisme melalui system adenylat cyclase (Gambar 3) (Kegley and Spears, 1995; Yanagi et.al., 2002; Hardy et al., 2005).

Mekanisme tersebut (Gambar 3) menunjukkan bahwa pengaktifan cAMP (siklus Adenin Monophospate) menjadi solusi bagi ternak yang mengalami cekaman stress untuk memproduksi glukosa. Ketika konsumsi ransum menurun atau terhenti untuk mengurangi heat increment (produksi panas metabolik) (Yue et al., 2010) dan kebutuhan energi mendesak maka perombakan glikogen otot melalui cAMP menjadi salah satu jalur alternatif untuk penyediaan energi. Fenomena inilah yang menjadi alasan utama ketersedian glukosa dalam darah tetap lebih tinggi pada fase layer meskipun fase ini lebih cenderung mengalami stress. Namun dalam kisaran temperatur tinggi yang masih mampu ditolerir, mekanisme produksi energi tersebut masih mampu dipertahakan, tentunya semakin meningkat temperatur menjauhi zona nyamannya maka tindakan pertama untuk melangsungkan hidupnya adalah berhentinya produksi telur. Produksi glukosa secara totalitas diarahkan untuk mempertahankan metabolisme minimal dalam sel, sehingga ini pula yang menjadi alasan tidak akan terjadi konversi glukosa menjadi kolesterol. Dalam keadaan stress temperatur, maka mekanisme glukoneogenesis yang distimulan oleh cortisol juga meningkat dalam rangka penenuhan energi, sebagaiman pada Tabel dan Gambar 1 menunjukkan tidak terdapat perbedaan kadar kolesterol antara grower dan layer.

\section{KESIMPULAN}

Berdasarkan hasil penelitian dapat disimpulkan bahwa fase layer cenderung mengalami stress akibat cekaman panas. Stress yang masih mampu ditolerir pada fase layer ditunjukkan dengan kadar glukosa darah masih tinggi meskipun sedang memproduksi telur.

\section{UCAPAN TERIMA KASIH}

Penulis menyampaikan apresiasi dan terima kasih kepada kelompok penelitian Fisiologi Stress Ayam Petelur, telah banyak membantu pelaksanaan penelitian ini. Ucapan yang sama kepada Direktur CV. Pamulihan Farm Kuningan-Jawa Barat, telah memberi kesempatan untuk melaksanakan penelitian di Perusahannya. Begitu pula kepada tim Laboratorium Pusat Politeknik Kesehatan Bandung, telah menfasilitasi sebagian analisis sampel penelitian ini.

\section{DAFTAR PUSTAKA}

Aengwanich, W. 2007. Effects of High Environmental Temperature on Blood Indices of Thai Indigenous Chickens, Thai Indigenous Chickens Crossbred and Broilers. International Poult. Sci. 6, 427-430.

Bell, O.J. and B.M. Freeman. 1971. Physiology and Biochemistry of The Domestic Fowl. Vol. 3. Academic Press London.

Dawson, W. R., and G. C. Whittow. 2000. Regulation of body temperature dalam G. C. Whittow : Sturkie's Avian Physiology. Academic Press, 
New York, NY. Pages 343-379

Garriga , C. , R. R. Hunter, C. Amat, J. M. Planas , M. A. Mitchell, and M. Moreto . 2006 . Heat stress increases apical glucose transport in the chicken jejunum. Am. J. Physiol. Regul. Integr. Comp. Physiol. 290 , 195 - 201.

Gomperts, B. D., I. M. Kramer and P. E. R.Tatham. $2009 . \quad$ Signal Transductions. Elsevier San Diego, USA.

Hardy, M. P. , H. B. Gao , Q. Dong, R. Ge, Q. Wang, W. R. Chai, X. Feng, and C. Sottas. 2005 . Stress hormone and male reproductive function. Cell Tissue Res. $322: 147$ - 153 .

Hicks, T. A. , J. J. McGlone, C. S. Whisnant , H. G. Kattesh , and R. L. Norman . 1998. Behavioral, endocrine, immune, and performance measures for pigs exposed to acute stress. J. Anim. Sci. $76: 474-483$.

Kegley, E.B., and Spears, J.W. 1995. Immune response, glucose metabolism, and performance of stressed feeder calves fed inorganic and organic chromium. J.Anim.Sci., 73,2721

Mahmoud, K.Z., , S. M. Gharaibeh, Hana A. Zakaria and Amer M. Qatramiz, 2010. Garlic (Allium sativum) Supplementation: Influence on Egg Production, Quality, and Yolk Cholesterol Level in Layer Hens. Asian-Aust. J. Anim. Sci. 23, 1503 1509 .

Mumma, J.O., J. P. Thaxton, Y. VizzierThaxton, and W. L. Dodson. 2006. Physiological Stress in Laying Hens. Poult. Sci. 85, 761-769.

Puvadolpirod, S. and J. P. Thaxton. 2000. Model of Physiological Stress in Chickens 1. Response Parameters. Poult. Sci. 79, 363-369.
Rahardja, D. P. 2010. Ilmu Lingkungan Ternak. Penerbit Masagena, Makassar.

Shinder, D., M. Rusal, J. Tanny, S. Druyan, and S. Yahav. 2007. Thermoregulatory responses of chicks (gallus domesticus) to low ambient temperatures at an early age. Poult. Sci. 86, 2200-2209.

Steel, R.G.D. dan J.H. Torrie, 1993. Prinsip dan Prosedur Statistika, suatu pendekatan biometric. Gramedia Pustakan Utama, Jakarta

Tan, G.Y., L. Yang, Y.-Q. Fu , J.H. Feng, and M.H. Zhang. 2010. Effects of different acute high ambient temperatures on function of hepatic mitochondrial respiration, antioxidative enzymes, and oxidative injury in broiler chickens. Poult. Sci. 89, 115-122.

Von Borell, E.H. 2001. The biology of stress and its application to livestock housing and transportation assessment. J. Anim Sci. 79, E260-E267.

Yahav, S. 2000. Domestic fowl-Strategies to confront environmental conditions. Poult. Avian Biol. Rev. 1, 81-95.

Yahav, S., A. Straschnow, D. Luger, D. Shinder, J. Tanny, and S. Cohen. 2004. Ventilation, sensible heat loss, broiler energy, and water balance under harsh environmental conditions. Poult. Sci. 83, 253-258.

Yanagi, T. Jr., H. Xin, and R. S. Gates. 2002. Optimization of partial surface wetting to cool caged laying hens. Appl. Eng. Agric. 45, 1091-1100.

Yue, H.Y., L. Zhang, S. G. Wu , L. Xu , H. J. Zhang, and G. H. Q. 2010. Effects of transport stress on blood metabolism, glycolytic potential, and meat quality in meat-type yellowfeathered chickens. Poult. Sci. 89, 413-419. 